\title{
Canalicular Multispecific Organic Anion Transporter 1
}

National Cancer Institute

\section{Source}

National Cancer Institute. Canalicular Multispecific Organic Anion Transporter 1. NCI

Thesaurus. Code C103884.

Canalicular multispecific organic anion transporter 1 (1545 aa, $174 \mathrm{kDa}$ ) is encoded by the human $A B C C 2$ gene. This protein is involved in both anion transport and multidrug resistance. 